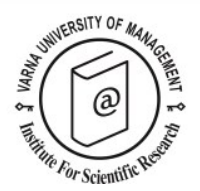

\title{
The importance of different culinary aspects when travelling - the case of international tourists to South Africa
}

\author{
Lisa-Mari Coughlan ${ }^{1 *}$ and Melville Saayman ${ }^{2}$
}

Received: 25/01/2017 Accepted: 05/07/2017

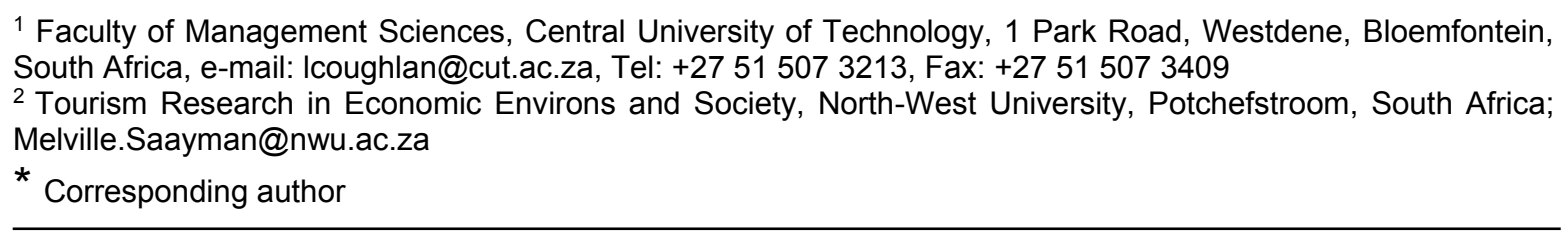

\section{Abstract}

Tourists spend a good portion of their travel budget on food and beverages. Culinary preference knowledge should thus be important to numerous stakeholders. Little is, however, known about the determinants of culinary preferences of international tourists. Furthermore, in the context of developing countries, very little has been published about cuisine in tourism. The purpose of this research is to identify the determinants of culinary preferences of international tourists to South Africa. A newly developed questionnaire based on literature was completed by 627 international tourists. Five culinary preference factors were identified from the results of the study, namely social influence, culture and religion, exploration, the culinary experience and environmental sensitivity. Social influence was the most important factor, followed by environmental sensitivity and then the culinary experience. Only two socio-demographic variables were found to influence the culinary preferences of international tourists to South Africa. Implications for each of the findings are put forth. Specific recommendations are also made to national and provincial government, tourism marketers and dining establishments alike, in order to reap the numerous benefits associated with culinary preference knowledge.

(C) 2018 Varna University of Management. All rights reserved

Keywords: culinary preferences; determinants; international tourists; South Africa.

Citation: Coughlan, L., M. Saayman (2018) The importance of different culinary aspects when travelling - the case of international tourists to South Africa. European Journal of Tourism Research 18, pp. 95-119

\section{Introduction}

Food consumption plays a vital role in shaping the total tourist experience (Du Rand \& Heath, 2006; Ignatov \& Smith, 2006; SánchezCañizares \& López-Guzmán, 2012), and the demand for culinary experiences among tourists is rising (Fields, 2002). A study by Saayman and Scholtz (2012) indicated that tourists to national parks in South Africa spent $24 \%$ of their total expenditure on food. It is also estimated that foreign tourists spent R7.4 billion on food in South Africa in 2013. This translates 
The importance of different culinary aspects when travelling - the case of international tourists to South Africa.

into just over $10 \%$ of the total amount international tourists spent during their stay in South Africa (South African Tourism, 2014).

This high expenditure on food in tourist destinations provides justification for researchers to investigate tourists' food concerns (Amuquandoh, 2011). Furthermore, a contribution can be made to the successful attainment of three of the South African National Department of Tourism's (2011) National Tourism Sector Strategy (NTSS) objectives by gaining knowledge of tourists' culinary preferences. The three objectives referred to are: "to grow the tourism sector's absolute contribution to the economy", "to deliver a world-class visitor experience", and "to position South Africa as a globally recognised tourism destination brand".

According to Rozin and Vollmecke (1986), food preference assumes the availability of at least two different items, and a decision being made to choose the one item over the other. The beverage component of tourists' food experience should, however, not be ignored. Consequently, for the purposes of this paper, the term culinary preference is preferred.

There are numerous benefits that could be derived from a critical assessment of culinary preferences, including economic growth (Torres, 2002; Mak, Lumbers, Eves \& Chang, 2012), policy development (National Department of Tourism, 2011; Wongprawmas \& Canavari, 2015), enhanced marketing strategies (Du Rand \& Heath, 2006; Chatibura, 2015), improved branding (Sánchez-Cañizares \& López-Guzmán, 2012; Blichfeldt \& Halkier, 2014; Steyn, 2015; United Nations, 2015), better-quality food and beverage (Torres, 2002:303; Sánchez-Cañizares \& LópezGuzmán, 2012:243; Du Plessis, Saayman \& Van der Merwe, 2015:9 \& 11-12), assistance with menu development (Batra, 2008; Kim, Eves \& Scarles, 2009; Amuquandoh, 2011), more enjoyable culinary experience (Ivanovic, 2008; Chang, Kivela \& Mak, 2010; National Department of Tourism, 2011), sustainable competitiveness (Hall, 2004; Du Rand \& Heath, 2006; Ivanovic, 2008; Amuquandoh, 2011) and culinary satisfaction (Mak et al., 2012; Andersen \& Hyldig, 2015; Lagerkvist, Normann \& Åström, 2017).

96
There is, however, a general scarcity of studies that examine cuisine as an element of tourism (Torres, 2002; Cohen \& Avieli, 2004; Ignatov \& Smith, 2006; Chang et al., 2010; Williams, Williams \& Omar, 2014). Du Rand and Heath (2006) further state that very little has been published regarding cuisine in developing countries, such as South Africa and more research into culinary tourism is needed especially in identifying the culinary preferences of international visitors. Culinary knowledge obtained can assist in the possible development of culinary destinations in South Africa. Strategies to empower and educate the South African tourism and hospitality industry and international tourists could result from knowledge on determinants of culinary preferences. Menus compiled by hotels, restaurants and other food and beverage providers could be developed on the basis of the culinary requirements of international tourists to South Africa. Therefore, the aim of this paper was to identify the determinants of culinary preferences of international tourists to South Africa.

In order to address the abovementioned aim the paper is divided into sections. The following section focusses mainly on a list of determinants of culinary preferences obtained from the literature. The methodology used to test whether these determinants are important to international tourists to South Africa is discussed thereafter. The results of the employed methodology is put forth. The findings, implications, conclusions and recommendations form the concluding sections of the paper.

\section{Literature review}

In 2014, South Africa was listed as the 30th most popular tourism destination with regard to its international tourism arrivals (United Nations, 2015). Ivanovic (2008) states that South Africa's heritage and cultural resource base is among the most diversified in the world and this potential should be exploited. Former Minister of Tourism, Derek Hanekom, similarly states that "Africa is a continent of unparalleled opportunity, and tourism is where the greatest untapped opportunity lies" (Moodley, 2016). More specifically, Du Rand and Heath (2006) agree that although South Africa is rich in 
culinary resources and opportunities, the country has not capitalised on its culinarytourism potential. According to Du Rand and Heath (2006), there has been a lack of awareness of the tourism potential of local food in the country, hence food has not been promoted as a tourism attraction. This seems true, even eleven years later, and these statements demonstrate that there is currently no strong focus on culinary tourism in South Africa. This is confirmed by the International Culinary Tourism Association and the International Culinary Tourism Development Organisation who ranked South Africa as the least-prepared culinary travel destination and the travel destination with the greatest potential for growth (Phillips, 2010).

An in-depth knowledge of the determinants of tourists' culinary preferences could make an important contribution to the development of quality culinary tourism products that lead to tourist satisfaction (Fields, 2002; Mak et al., 2012) and prepare South Africa as a culinary travel destination. Many categories of determinants have been offered in the literature, but for the purposes of this paper three categories are proposed, namely: sociodemographic, behavioural and external. A discussion of each category of determinants follows (each determinant being stated in bold when first addressed).

\section{Socio-demographic determinants}

Socio-demographic variables include religion and culture, intolerances and allergies, nationality, education, gender and age. Age has often been cited as a determinant of culinary preferences (Wądołowska, BabiczZielińska \& Czarnocińska, 2008; Mak et al., 2012; Barcelona Field Studies Centre, 2015). Aquilani et al. (2015) found individuals aged between 42 and 49 years to be more likely to drink craft beer than individuals aged between 18 and 25 years. In Hong-Kong and Australia, tourists considering themselves to be "culinary tourists' tended to be younger respondents, while 'non-culinary tourists' were mainly older tourists (McKercher, Okumus \& Okumus, 2008; Robinson \& Getz, 2014).

In the same Hong-Kong study, no differences were found in the gender profile of tourists across different culinary tourism segments (McKercher et al., 2008). Other researchers who found similar results include Ayo et al. (2012), Devi et al. (2015) and SánchezCañizares and López-Guzmán (2012). Opposing the statement that gender and culinary preferences are unrelated, Amuquandoh (2011), Mak et al. (2012), Robinson and Getz (2014) declare that a definite relationship exists. Women are often known to be more nutrition-conscious than men (Wądołowska et al., 2008; Amuquandoh, 2011) and have been found to be especially excited and interested in tasting local food while on holiday (Kim et al., 2009; D’Antuono \& Bignami, 2012).

Further differences in culinary preferences could result from men and women's educational level (Wądołowska et al., 2008; Ayo et al., 2012). In Fiji, educational level was the only variable significantly contributing to and explaining variance in consumer culinary preferences (Devi et al., 2015). Tourists with a higher educational level have been found to be more concerned with learning about cultures and the healthiness of culinary items (Kim et al., 2009) and have been more open to trying new foods (D'Antuono \& Bignami, 2012). However, education does not necessarily always affect the importance of food during a trip (McKercher et al., 2008; SánchezCañizares \& López-Guzmán, 2012).

The culinary preferences of individuals of differing nationalities are also a point of interest. Tourists from North America, Europe and Scandinavia have been found to be concerned with the availability of information on traditional foods in Ghana. Amuquandoh (2011) attributes this to the fact that most tourists from these countries might travel in search of new foods to try. On the other hand, Asian tourists have been found to shun new foods, preferring their own foods (Cohen \& Avieli, 2004). This means that they will be averse to visit a destination unless it features restaurants serving their national cuisine. In addition to "conservative" Asian tourists, American tourists have also been found to be conservative in their culinary preferences. They were less likely to try out local foods than non-American tourists in the Yucatan Peninsula, Mexico 
The importance of different culinary aspects when travelling - the case of international tourists to South Africa.

(Torres, 2002). Sánchez-Cañizares and LópezGuzmán (2012) conversely found no relationship between the importance of food during the trip and nationality.

Cultural dislikes for certain foods and dietary laws in religion have been documented to influence culinary preferences (Steptoe et al., 1995; Chang et al., 2010; Horng \& Tsai, 2010; Amuquandoh, 2011; Falguera, Aliguer \& Falguera, 2012; Mak et al., 2012). What is considered unacceptable food in one culture may be considered delicious in another culture. For example, raw fish is enjoyed by most Japanese, but considered unhealthy by most Chinese (Su, 2015). International tourists in Ghana have been particularly concerned of being served unknown meat that could be culturally unacceptable (Amuquandoh, 2011:4). Similarly, Israelis departing for Asia are commonly concerned that they might not find anything they are willing to eat there. Some of them even take along basic foodstuffs, such as instant meals and crackers. A number of these concerns and precautions are attributed to culturally unacceptable food such as cat, dog and reptile meat, as well as the Jewish dietary laws known as Kashrut or kosher (Cohen \& Avieli, 2004:760). Muslims, on the other hand, consume food that is referred to as halal. Halal foods are poultry, fish, fruit, vegetables, all grains, and meat slaughtered in a prescribed manner. No shellfish, pork or alcohol is allowed (Horng \& Tsai, 2010; Hattingh, 2015). Hindus also generally restrict or avoid alcohol and are mostly vegetarian, some consuming dairy products (Hattingh, 2015).

Not only Hindus are vegetarians. Some individuals prefer a vegetarian diet due to health concerns or their concern for animal rights. Vegetarianism refers to a diet that excludes meats and other animal products. There are many vegetarianism variations, of which the strictest is veganism (Hattingh, 2015).

Lastly, it is important to note that intolerances and allergies influence culinary preferences (Packaged Facts, 2014; Sloan, 2015). Recent studies indicate that there has been a marked increase in the prevalence of food allergies. There are many possible factors which might cause a person to develop an allergy, such as genetics, changes in what are consumed, the global focus on food hygiene and other environmental factors (Allergy UK, 2015). Whereas a food allergy causes an immune system reaction which affects numerous organs and can be life-threatening, a food intolerance is generally less serious and mostly limited to digestive problems. Food intolerances can be caused by the absence of an enzyme needed to fully digest the food, irritable bowel syndrome, food poisoning, sensitivity to food additives, recurring stress, psychological factors or celiac disease $(\mathrm{Li}$, 2014).

\section{Behavioural determinants}

Behavioural determinants include past experience, the need for self-development, social influences, travel experience and frequency of travel, desire for an authentic food experience, type of tourist, personality, lifestyle, and taste. An individual's taste has an effect on their culinary preferences (Wongprawmas \& Canavari, 2015), which according to Kittler and Sucher (2004) and Updyay and Sharma (2014:35), dominates the dietary domain of tourists. International tourists in Bangkok indicated that their taste is an important factor influencing their preference for dining at ethnic restaurants (Batra, 2008:12 \& 16). In India again, tourists have indicated that Indian cuisine was spicy, hot and unpalatable and consequently did not accommodate their tastes (Abraham \& Kannan, 2015).

The lifestyles of tourists might also determine the culinary decisions made whilst on holiday (trends that impact on individuals' lifestyles, such as eating organic food, are discussed under external determinants of culinary preferences). Culinary preferences are often influenced by weight (Steptoe et al., 1995) and health preoccupations (Chang et al., 2010; Amuquandoh, 2011; Falguera et al., 2012) with some tourists believing that local foods made with local ingredients are fresher and could improve their health (Kim et al., 2009). Some destinations offer cuisine claimed to have a positive impact on health, these include the Mediterranean Diet in Greece and Italy and the Atlantic diet in Portugal (Fields, 2002).

Not only chosen lifestyles influence culinary preferences, but also the different types of 
tourists. Torres (2002) describe types of tourists to range from being flexible and adventurous to being highly organised and conservative mass tourists. The variety of foods demanded by tourists, especially concerning local versus imported foods, has been found to be closely linked to the type of tourist. The author found adventurous tourists to value access to the local Yucatec food considerably more than mass tourists did. Similarly, Cohen and Avieli (2004) state that recreational tourists (tourists mainly seeking to relax) tend to show predominantly neophobic tendencies by consuming familiar food and beverages, while experiential tourists will be interested in local food, showing neophylic tendencies. Food neophobia is a food-related personality trait that influences tourist food consumption (Mak et al., 2012). Food neophobia is perceived as both personality and behaviour (Kim et al., 2009) and the concept has also been referred to as familiarity (Steptoe et al., 1995). Neophobic individuals tend to avoid novel and unfamiliar food, while neophylic individuals are attracted to novel foods (Blichfeldt \& Halkier, 2014). Burusnukul, Binkley and Sukalakamala (2011) and Mak et al. (2012) state that, based on this concept, persons commonly prefer foods with which they are familiar.

Mak et al. (2012) also state that past experience influences tourists' food consumption. This is reiterated in the literature (Chang et al., 2010; Amuquandoh, 2011; Falguera et al., 2012). It could be an experience as simple as eating similar or stereotyped food in their home country (Abraham \& Kannan, 2015). Furthermore, travel experience might broaden the horizons of individuals beyond their general past experience. McKercher et al. (2008) found people classifying themselves as non-culinary tourists to be mainly first-time tourists, whereas definite culinary tourists were repeat visitors. The less experienced traveler may seek comfort in familiar foods when in an unfamiliar holiday destination (Fields, 2002). Conversely, food neophobia has been found to be lower in people who had travel experience (D'Antuono \& Bignami, 2012) and the well-travelled are more willing to try local cuisine (Ryu \& Jang, 2006). The desire for an authentic experience of food has been stated to be an attribute influencing tourist food consumption decisions (Burusnukul et al., 2011).

Chinese group tourists consider the tasting of local food to be an opportunity to meet with their family and others. These social influences enrich their travel experience (Su, 2015). A main predictor of Setswana food consumption behaviour has been found to be the presence of others (Chatibura, 2015). Kim et al. (2009) and Kim and Eves (2012) state that this theme revealed that local food experience has a role in ego-enhancement. Fields (2002:39-40) agrees, stating that "eating in the 'right' restaurant and being seen to eat there has always been an important means of drawing status distinctions". Reference groups have also been found to be influential in deciding to travel to a wine region for tourism purposes (Sparks, 2007). Another social influence could be the ratings on travelogues such as TripAdvisor. This can certainly be imagined as TripAdvisor has 340 million users and 4 million listed restaurants (Smith, 2016).

The need for self-development may ultimately influence tourists' culinary preferences. Cooking classes and trade shows in tourist destinations are popular as people feel the need to be creative and better themselves. These occasions give them the opportunity to do just that (Tikkanen, 2007; Daniel, Guttmann \& Raviv, 2011). The last behavioural determinants to note are hunger, thirst and mood. Although these determinants most certainly influence food consumption decisions (Steptoe et al., 1995; Mak et al., 2012), they are fleeting. These determinants are therefore not relevant to the culinary preferences on an overall trip as mood, hunger and thirst would have varied across the moments (Fields, 2002; Kim et al., 2009; Kim \& Eves, 2012) and days of the trip.

\section{External determinants}

Determinants of culinary preferences in the external environment include hygiene perception, availability, quality and variety, dining establishments, affordability, communication gap, trends and marketing. Many destinations and regions use food and beverages as a tourism marketing tool, but 
often these marketing efforts are not optimised (Fields, 2002). Marketing strategies (or the lack thereof) employed in destinations could influence the culinary preferences of tourists. For example, international tourists in Ghana reported a lack of information being available to identify assorted local foods, suspicion of being cheated, and difficulty in ordering local foods (Amuquandoh, 2011).

Tourists to Bangkok and members of online travel communities and travel groups value menus available in English (Batra, 2008; Ab Karim \& Chi, 2010). Communication is a frequent cause of tourists avoiding local culinary establishments, even if they wish to visit them. The culinary experience is diminished (Burusnukul et al., 2011) when tourists experience difficulty in identifying and ordering local dishes (Cohen \& Avieli, 2004) and communicating with staff in general (Abraham \& Kannan, 2015).

A study conducted in Cancun found that many tourists express a strong interest in trying local food, but do not feel that they had sufficient opportunity to do so (Torres, 2002). Availability, quality and variety of food and beverages, therefore, influence consumption (Rozin \& Vollmecke, 1986; Steptoe et al., 1995; Updhyay \& Sharma, 2014; Abraham \& Kannan, 2015; Wongprawmas \& Canavari, 2015). Cohen and Avieli (2004) state that while some tourists may prefer familiar food, they may select food of a higher quality and in larger quantities than they consume in their daily lives. The higher respondents value quality above other characteristics of beer, the more likely they have been found to prefer craft beer above commercial beer (Aquilani et al., 2015). The sensory appeal of cuisine, involving smell, taste and appearance are important in the culinary decision-making process (Steptoe et al., 1995; Kim \& Eves, 2012).

This having been said, culinary preferences are largely determined by cost or affordability (Rozin \& Vollmecke, 1986; Steptoe et al., 1995; Wongprawmas \& Canavari, 2015). A reasonable price for dining out is critical to enticing tourists (Ab Karim \& Chi, 2010) for where and what they eat will depend on their travel budget (Burusnukul et al., 2011).
The international community have long questioned the wholesomeness of food from Africa and where and what to eat often depend on hygiene perception (Amuquandoh, 2011). Hygiene perception has been found to be a major challenge obstructing tourist motivation (Abraham \& Kannan, 2015). Tourists, particularly those traveling to developing countries, tend to avoid the consumption of certain local foods due to the fear of illness (Cohen \& Avieli, 2004).

Not only the safety of the food itself but also the cleanliness of restaurants seems to be key in tourists' decisions to consume local food and beverages (Kim et al., 2009). Fields (2002) further states that if a dining establishment disappoints in its décor, lighting, air conditioning, acoustics, furnishing or size and shape of the room they may spoil the entire experience of dining out. Parents also value establishments who can cater to their children and families with children spend a significant amount of money dining out (White Hutchinson, 2007; McDonald, 2014). Lastly, when choosing a restaurant the location of a dining establishment is important as many factors related to the location may influence tourists decision-making (Restaurant Engine, 2015; Argyle, 2016).

All of these external determinants are linked to another determinant, namely trends. Armed with the latest guidebooks, some tourists are on a look out for the trendiest destinations (Croce \& Perri, 2010). Global trends in the culinary domain are numerous, and since they can alter behaviour, it is important to consider them. Many of these trends can be summarised under the heading "mindful dining", which illustrates that consumers are aware that their dining decisions impact both their own health as well as the health of the environment (Stanton, 2015). Noteworthy trends include clean eating and whole food (Steptoe et al., 1995; Merriam-Webster Dictionary, 2015; Stanton, 2015), functional, organic and animal welfare-oriented products (Torres, 2002; Falguera et al., 2012; Bigliardi \& Galati, 2013; Napolitano, Castellini, Naspetti, Piasentier, Girolami, et al., 2013; Getz, Robinson, Andersson \& Vujicic, 2014; de Jonge, van der Lans \& van Trijp, 2015), 
rejection of low cost mass production food (Barcelona Field Studies Centre, 2015; Yeoman \& McMahon-Beattie, 2015), buying local (Barcelona Field Studies Centre, 2015; Yeoman \& McMahon-Beattie, 2015), environmental sustainability (Steptoe et al., 1995; Stanton, 2015), trading up (Barcelona Field Studies Centre, 2015; Wahba, 2016), celebrity chefs (Croce \& Perri, 2010; Food and Beverage Magazine, 2014; Barcelona Field Studies Centre, 2015), craft beer (Aquilani et al., 2015; Elzinga, Tremblay \& Tremblay, 2015; Gómez-Corona, Lelievre-Desmas, Escalona Buendía, Chollet \& Valentin, 2016) and garage wines (Gardner, 2014; Ronco, 2015).

The successful outcome of a tourist visit depends largely on actors of the supply-side having a thorough knowledge of the determinants of culinary preferences (Croce \& Perri, 2010), which prompts further investigation.

\section{Methodology}

The methodology used to test if the list of determinants identified in the literature review applies in a South African context is detailed next. A quantitative research design was better suited to this study than a qualitative design, due to the numerous encompassed variables (Leedy \& Ormrod, 2014).

\section{Questionnaire}

The aim of the questionnaire was to include most of the determinants of culinary preferences identified in various literary resources. The newly developed questionnaire was based on existing questionnaires, including, but not limited to, those of Amuquandoh (2011), Chatibura (2015), McKercher et al. (2008), Sánchez-Cañizares and López-Guzmán (2012) and Torres (2002).

Section A captured the respondents' sociodemographic characteristics. Section A further captured behavioural determinants of culinary preferences which could not be captured on the five-point scale, namely past experience, travel experience and frequency of travel, type of tourist and personality. Section B focused on the respondents' culinary preferences mainly based on the external and behavioural determinants found in the literature. Respondents were asked to rate 32 items relating to their culinary preferences on a fivepoint scale to indicate their importance, ranging from "not at all important" (1) to "extremely important" (5). Reliability and validity of the questionnaire were established.

\section{Sample and survey}

Data was gathered over a period of three months: data collection commenced at the end of May 2016 and concluded in the first week of August 2016. International tourists awaiting flights in the departure halls of O.R. Tambo International Airport's international terminals was the sample. In 2015, foreign departures from O.R. Tambo International Airport were 2327 439. This accounts for $77.8 \%$ of all airport departures of foreigners from the country (Statistics South Africa, 2016). Krejcie and Morgan (1970) calculated that for a population exceeding 1 million, a sample size of 384 is required. To ensure that a representative sample of international tourists in South Africa was acquired, an attempt was made to acquire a larger sample than those proposed by Leedy and Ormrod (2014) and Krejcie and Morgan (1970). A sample of 600 was thus proposed. Also aiding in the pursuit for a representative study sample, random sampling was used in order to give each international tourist an equal opportunity to be selected.

Experienced and senior field workers were deployed to collect the data. Fieldworkers introduced themselves to travellers in the departure halls of the O.R. Tambo International Airport's international terminals. The fieldworkers explained to potential respondents the overall objectives of the research and requested the travellers' permission to conduct the study. A series of questions were used to determine whether or not participants met the inclusion criteria, namely being over the age of 18, understanding English, being non-residents of South Africa and having stayed in South Africa overnight. Those who were eligible were asked to voluntarily participate in the study by completing the self-administered questionnaire. Fieldworkers remained with the respondents while they completed the questionnaire in case the respondent required clarity on any of the questions or preferred to complete the questionnaire in a face-to-face interview 
manner. In total, 664 questionnaires were completed, of which 627 questionnaires were useable for the final analysis.

\section{Statistical analysis}

Microsoft Excel version 2013 was used to analyse the data. Descriptive statistics in the form of frequencies (in percentage format), means and standard deviations were computed. Exploratory factor analysis (EFA) was used to identify groups of highly interrelated culinary preference determinants that reveal underlying themes (Leedy \& Ormrod, 2014).

The t-test assesses the statistical difference between two sample means for a dependent variable (Hair, Black, Babin \& Anderson, 2010). The t-test was employed to reveal whether there were significant differences in tourists' determinants of culinary preference in terms of their socio-demographic and travel profiles (behavioural determinants). Spearman's rank order correlation analyses ranked variables and were thus used to determine whether correlations exist between the ranked sociodemographic and travel profile variables and the culinary preference factors (Kline, 2016). ANOVA compares the differences between three or more means (Leedy \& Ormrod, 2014). ANOVA was used to compare the remaining socio-demographic and travel profile variables, which could not be analysed by means of $\mathrm{t}$ tests or correlation analyses, with the culinary preference factors.

\section{Results}

\section{Socio-demographic and travel profile}

The socio-demographic findings is put forth in Table 1. Most $(78.66 \%)$ of the 627 respondents

Table 1. Socio-demographic frequencies

\begin{tabular}{|c|c|c|c|}
\hline Characteristics & Detail & Frequency & Percentage \\
\hline \multirow{5}{*}{$\begin{array}{l}\text { Age } \\
(n=614)\end{array}$} & $18-25$ & 159 & $25.90 \%$ \\
\hline & $26-35$ & 169 & $27.52 \%$ \\
\hline & $36-45$ & 155 & $25.24 \%$ \\
\hline & $46-55$ & 68 & $11.07 \%$ \\
\hline & $56+$ & 63 & $10.26 \%$ \\
\hline \multirow{2}{*}{$\begin{array}{l}\text { Gender } \\
(n=624)\end{array}$} & Male & 365 & $58.49 \%$ \\
\hline & Female & 259 & $41.51 \%$ \\
\hline \multirow{3}{*}{$\begin{array}{l}\text { Educational level } \\
(n=611)\end{array}$} & Secondary school or less & 82 & $13.42 \%$ \\
\hline & Vocational training & 70 & $11.46 \%$ \\
\hline & University degree & 459 & $75.12 \%$ \\
\hline \multirow{5}{*}{$\begin{array}{l}\text { Nationality } \\
(\mathrm{n}=615)\end{array}$} & Africa & 309 & $49.28 \%$ \\
\hline & Americas & 117 & $18.66 \%$ \\
\hline & Australia and Oceania & 15 & $2.39 \%$ \\
\hline & Europe & 109 & $17.38 \%$ \\
\hline & Asia & 66 & $10.53 \%$ \\
\hline \multirow{3}{*}{$\begin{array}{l}\text { Neophilic versus neophobic tendency (type } \\
\text { of tourist and personality) } \\
(n=575)\end{array}$} & Adventurous & 290 & $50.43 \%$ \\
\hline & Slightly adventurous & 209 & $36.35 \%$ \\
\hline & Not at all adventurous & 76 & $13.22 \%$ \\
\hline \multirow{7}{*}{$\begin{array}{l}\text { Following any religious, health- or weigh- } \\
\text { related diet (cultures and religion, } \\
\text { intolerances and allergies and lifestyle) } \\
\text { ( } n=616) \\
\text { If following a diet, which diet (cultures and } \\
\text { religion, intolerances and allergies and } \\
\text { lifestyle) } \\
(n=40)\end{array}$} & Yes & 78 & $12.66 \%$ \\
\hline & No & 538 & $87.34 \%$ \\
\hline & Vegan & 5 & $7.35 \%$ \\
\hline & Halal & 10 & $14.71 \%$ \\
\hline & Vegetarian & 17 & $25.00 \%$ \\
\hline & Low carb & 4 & $5.88 \%$ \\
\hline & Weight & 4 & $5.88 \%$ \\
\hline
\end{tabular}


were under the age of 46 years. There was more male $(58.49 \%)$ than female $(41.51 \%)$ respondents. An overwhelming majority of $75.12 \%$ of the respondents indicated that they held a university degree. Almost half (49.28\%) of the respondents from the current study were from African countries. The African countries most frequently stated were Zambia, Tanzania, Namibia, Malawi and Kenya. The other respondents were mainly divided between Americans (18.66\%), Europeans (17.38\%) and Asians (10.53\%), with only a few respondents from Australia and Oceania (2.39\%).

This trip was the first visit to South Africa for $43 \%$ of respondents and more than half of respondents $(51.38 \%)$ stayed for less than one week, as can be seen in Table 2. For this study, only $20.7 \%$ of the respondents indicated that they were in South Africa for leisure purposes. An equal percentage of respondents $(20.7 \%)$ were visiting friends or relatives, whilst $37.71 \%$ of respondents indicated that they were in South Africa on business and $20.89 \%$ were in South Africa for other reasons.

In order to determine whether tourists displayed neophylic or neophobic tendencies, they were requested to state whether they would consider themselves to be adventurous whilst traveling in terms of whether they choose to try local cuisine. Half $(50.43 \%)$ of the

Table 2. Travel profile frequencies

\begin{tabular}{|c|c|c|c|}
\hline Characteristics & Detail & Frequency & $\begin{array}{c}\text { Percentage } \\
\text { and ZAR }\end{array}$ \\
\hline \multirow{5}{*}{$\begin{array}{l}\text { Frequency of dining out } \\
\text { (past experience) } \\
(\mathrm{n}=551)\end{array}$} & More than once a week & 150 & $27.22 \%$ \\
\hline & Once a week & 191 & $34.66 \%$ \\
\hline & Once a month & 132 & $23.96 \%$ \\
\hline & Less than once a month & 34 & $6.17 \%$ \\
\hline & Seldom & 44 & $7.99 \%$ \\
\hline \multirow{7}{*}{$\begin{array}{l}\text { Number of international } \\
\text { trips in the past five years } \\
\text { (travel experience and } \\
\text { frequency) } \\
(n=605)\end{array}$} & $1-5$ & 325 & $53.72 \%$ \\
\hline & $6-10$ & 142 & $23.47 \%$ \\
\hline & $11-15$ & 40 & $6.61 \%$ \\
\hline & $16-20$ & 46 & $7.60 \%$ \\
\hline & $21-25$ & 14 & $2.31 \%$ \\
\hline & $26-30$ & 11 & $1.82 \%$ \\
\hline & $31+$ & 27 & $4.46 \%$ \\
\hline \multirow{5}{*}{$\begin{array}{l}\text { Times visited South Africa } \\
\text { (travel experience and } \\
\text { frequency) } \\
(n=607)\end{array}$} & $1-5$ & 518 & $85.34 \%$ \\
\hline & $6-10$ & 60 & $9.88 \%$ \\
\hline & $11-15$ & 12 & $1.98 \%$ \\
\hline & $16-20$ & 8 & $1.32 \%$ \\
\hline & $21+$ & 9 & $1.48 \%$ \\
\hline \multirow{4}{*}{$\begin{array}{l}\text { Length of stay (taxonomy } \\
\text { question) } \\
(n=617)\end{array}$} & $1-7$ days & 317 & $51.38 \%$ \\
\hline & 8-14 days & 179 & $29.01 \%$ \\
\hline & 15-21 days & 64 & $10.37 \%$ \\
\hline & $22+$ days & 57 & $9.24 \%$ \\
\hline \multirow{6}{*}{$\begin{array}{l}\text { Type of accommodation } \\
\text { (taxonomy question) } \\
(n=517)\end{array}$} & Hotels & 251 & $48.55 \%$ \\
\hline & Resorts & 15 & $2.90 \%$ \\
\hline & Homes of friends and relatives & 138 & $26.69 \%$ \\
\hline & Campgrounds & 15 & $2.90 \%$ \\
\hline & Bed and breakfasts & 41 & $7.93 \%$ \\
\hline & Other & 57 & $11.03 \%$ \\
\hline
\end{tabular}




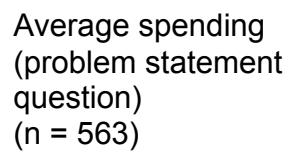

Favourite beverage during the trip (note: only most popular listed here) (problem statement question)

$(\mathrm{n}=542)$
Accommodation

Sight-seeing tours

Transport

Food and beverages

Packaged tours

Other

Leisure

Business

Visiting friends or relatives

Other

Yes

No

Not sure

Yes

No

Not sure

I did not know which items are local (marketing)

I was not sure about the health and safety of the local cuisine (hygiene perception)

I was not sure which ingredients the local dishes or beverages contain

I was not interested in trying local cuisine (personality, global trends: buying local)

The local cuisine did not look appetising (availability, quality and variety)

Other

\section{Chicken}

Pap (also referred to as ugali)

Steak

Indian/curry

Fish

Braai (also referred to as barbeque or BBQ)

Tea

Coffee and coffee-related drinks (e.g. latte and cappuccino)

Water

Wine

Soft drinks

Beer

Juice
R8 863.54

R3 516.14

251

R2 802.31

382

R3 080.22

96

R25 430.84

243

R6 201.37

112

$20.70 \%$

204

$37.71 \%$

112

$20.70 \%$

$113 \quad 20.89 \%$

$272 \quad 44.16 \%$

253

$41.07 \%$

91

$14.77 \%$

418

$68.86 \%$

147

$24.22 \%$

42

$6.92 \%$

125

$53.88 \%$

17

$7.33 \%$

$40 \quad 17.24 \%$

29

$12.50 \%$

6

$2.59 \%$

15

$6.47 \%$

82

$14.29 \%$

50

$8.71 \%$

47

$8.19 \%$

40

$6.97 \%$

33

$5.75 \%$

31

$5.40 \%$

40

$7.38 \%$

$55 \quad 10.15 \%$

68

$12.55 \%$

92

$16.97 \%$

71

$13.10 \%$

125

$23.06 \%$

73 respondents displayed neophylic tendencies and choose to 'always' try local cuisine. Just over a third $(36.35 \%)$ were neither neophylic nor neophobic as they occasionally tried local cuisine and $13.22 \%$ were neophobic, preferring cuisine they are used to.
When asked whether they are following any religious, health- or weight-related diets, $87.34 \%$ of the respondents stated that they were not. The $12.66 \%$ who were following diets, were following a great variety of different diets for different reasons. The diets and 
reasons most frequently cited included vegetarian $(25 \%$ of the respondents following a diet), halal $(14.71 \%)$ and vegan $(7.35 \%)$. Other noteworthy diets were low carbohydrate $(5.88 \%)$ and weight-loss diets $(5.88 \%)$. It should be noted that the diet cited most often in this study, namely vegetarianism, only made out $2.76 \%$ of the total sample. This finding is useful, as dining establishment management might have assumed more international tourists to be vegetarians since there are an estimated 375 million vegetarians worldwide (Figus, 2014).

Regarding religious diets, additional to halal, two respondents cited that they follow a Christian diet, one a Catholic diet and one a Hindu diet. Five respondents also indicated that they only consume certain meats. One respondent noted that they suffered from allergies and one suffered from avoidant food intake disorder.

\section{Importance of the different determinants of culinary preferences}

Respondents were asked to rate a number of items relating to their culinary preferences on a 5-point scale to indicate their importance, ranging from not at all important (1) to extremely important (5). The items and their corresponding variables have been emphasised in italics from this point onwards. From the 32 items tested, it can be seen in Table 3 that respondents regarded being able to order from a menu that is easily understandable (communication gap) to be the most important, with a mean rating of 3.708 . The second most important item for respondents in this study was the availability of cuisine that was reasonably priced (mean = 3.620). The third most important item was that the food had to appeal to the respondents' senses (mean $=3.596$ ). Some of the other important items noted by tourists in the current study include the availability of a wide variety of cuisine (mean $=3.519)$, the availability of information about local cuisine (mean $=3.426$ ) that forms part of marketing and the opportunity to experience a new culture through their cuisine (mean $=3.424)$.

The four items of least importance were the availability of kosher cuisine (with a mean of 2.356 ), the availability of vegan cuisine (mean

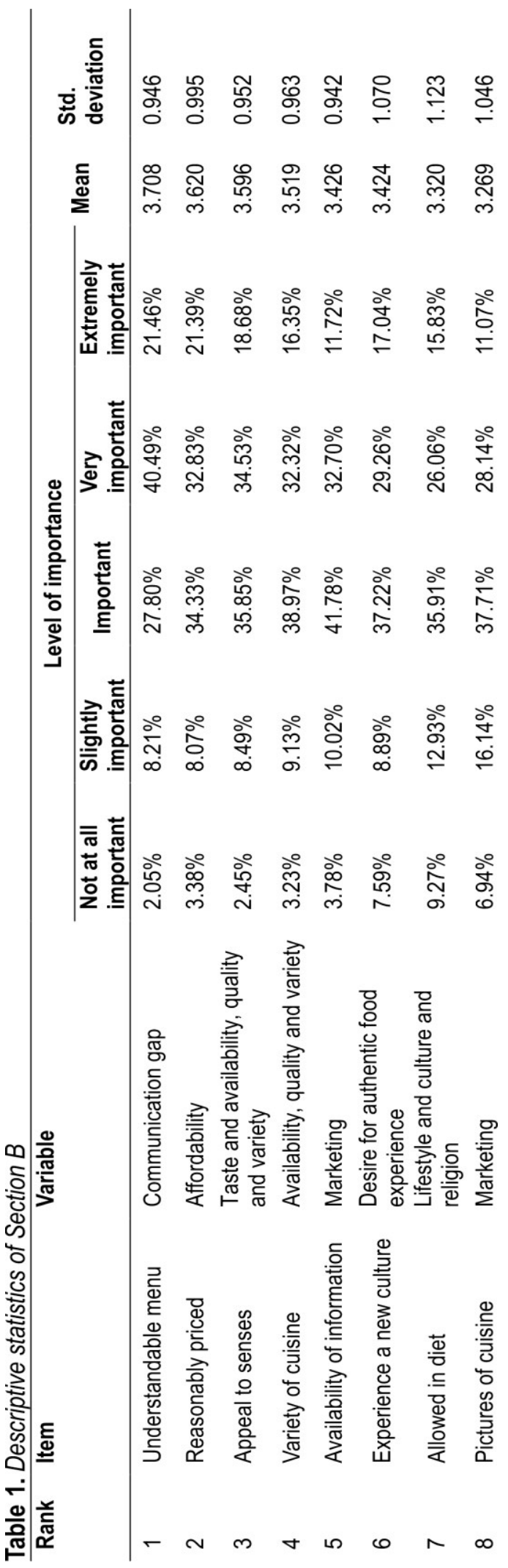




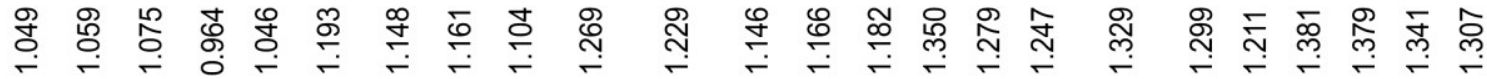

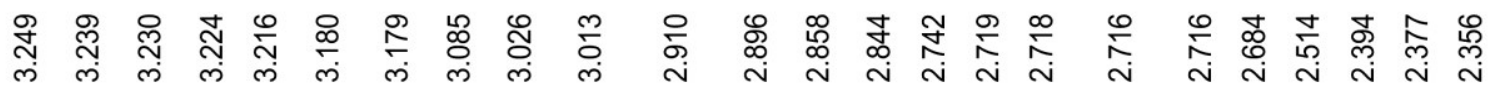

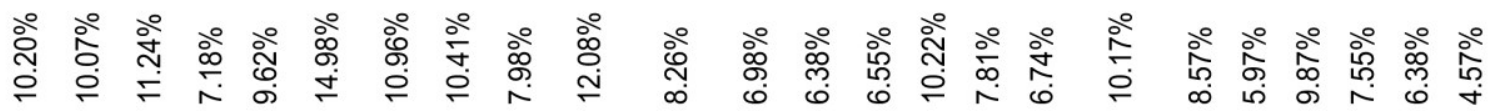

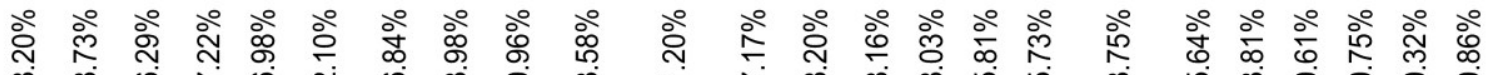

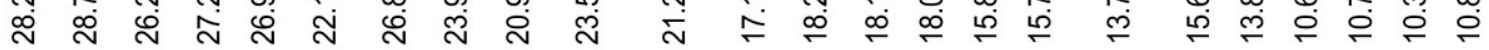

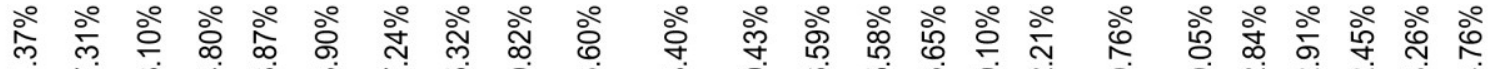

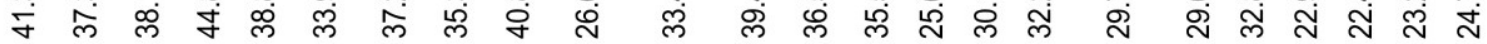

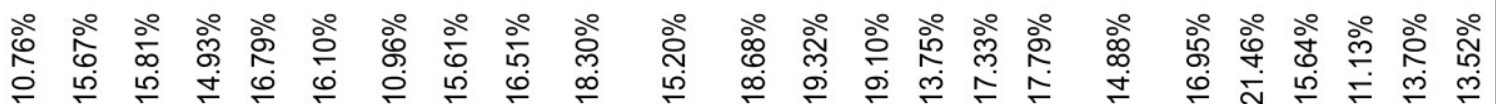

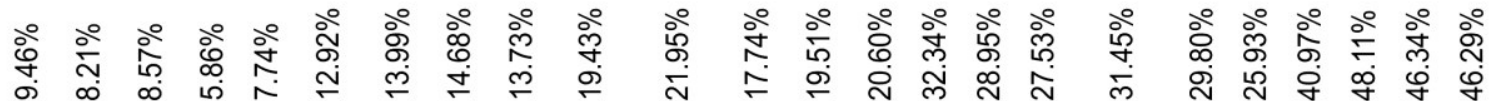

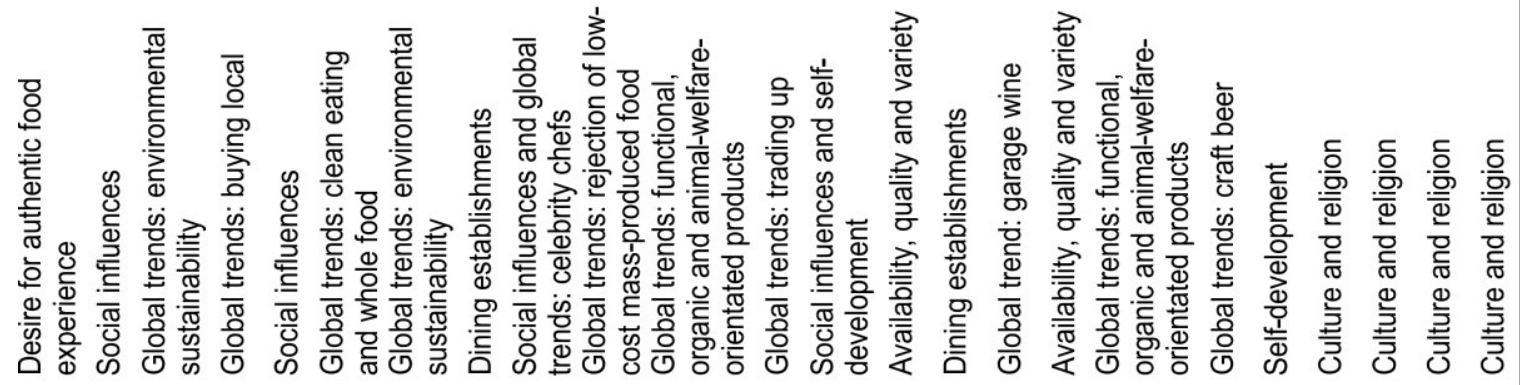

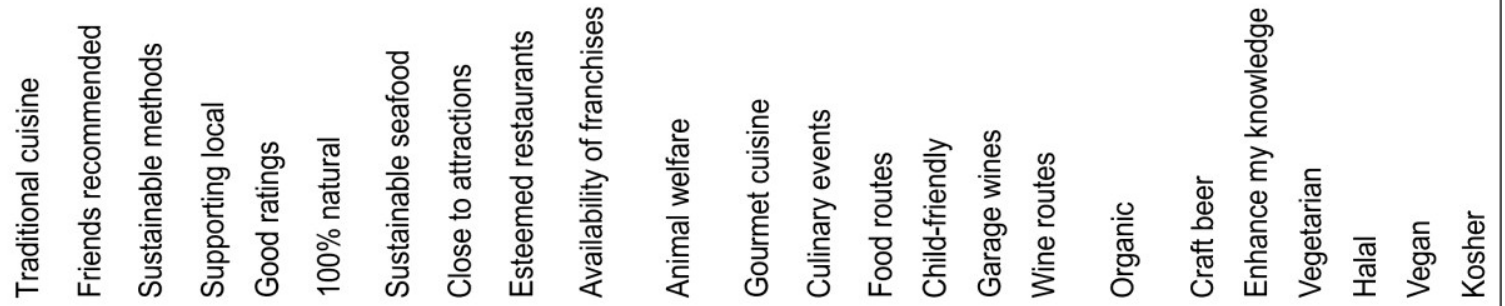
の 
$=2.377$ ), the availability of halal cuisine (mean $=2.394)$ and the availability of vegetarian cuisine (mean $=2.514)$. This may be due to the fact that you are either $100 \%$ affected by dietary laws in culture and religion or $0 \%$ affected by them, and very few respondents stated that they were following any of these diets in the socio-demographic section of the questionnaire. The standard deviations of these four items are all quite high, ranging from 1.307 to 1.381 .

\section{Culinary preferences}

A principal component analysis factor analysis with oblique rotation (Oblimin with Kaiser Normalization) was undertaken for both the culinary preference factors as well as the culinary satisfaction factors. The KMO measure of sampling adequacy was 0.886 , which is exceedingly acceptable according to Field (2013) and indicates an adequate sample size for factor analysis. The Bartlett's Test of Sphericity was also significant $(p<0.000)$. The items and their loadings onto each of the five factors are displayed in Table 4. The five factors explained $60.74 \%$ of the variance.

Each item was assigned to the factor on which it showed the strongest loading. Upon inspection of the item content, it was decided to name the five factors: "Social influence", "Culture and religion", "Exploration", "The

Table 4. Loadings of culinary preference factors

\begin{tabular}{|c|c|c|c|c|c|c|c|}
\hline \multirow[b]{2}{*}{$\frac{c}{o}$} & \multirow[t]{2}{*}{ Item } & \multirow[t]{2}{*}{ Variable } & \multicolumn{5}{|c|}{ Factors and loadings } \\
\hline & & & $\begin{array}{l}\text { Social } \\
\text { influence }\end{array}$ & $\begin{array}{l}\text { Culture } \\
\text { and } \\
\text { religion }\end{array}$ & $\begin{array}{l}\text { Explora } \\
\text { tion }\end{array}$ & $\begin{array}{l}\text { The } \\
\text { culinary } \\
\text { experien } \\
\text { ce }\end{array}$ & $\begin{array}{l}\text { Environ } \\
\text { mental } \\
\text { sensi-- } \\
\text { tivity }\end{array}$ \\
\hline 5 & $\begin{array}{l}\text { Availability of } \\
\text { information }\end{array}$ & Marketing & 00.702 & & & & \\
\hline 1 & $\begin{array}{l}\text { Understandable } \\
\text { menu }\end{array}$ & Communication gap & 00.653 & & & & \\
\hline 6 & $\begin{array}{l}\text { Pictures of } \\
\text { cuisine }\end{array}$ & Marketing & 00.651 & & & & \\
\hline 3 & Good ratings & Social influences & 00.651 & & & & \\
\hline 2 & $\begin{array}{l}\text { Friends } \\
\text { recommended }\end{array}$ & Social influences & 00.650 & & & & \\
\hline 7 & Appeal to senses & $\begin{array}{l}\text { Taste and availability, } \\
\text { quality and variety }\end{array}$ & 00.620 & & & & \\
\hline 8 & Allowed in diet & Lifestyle & 00.538 & & & & \\
\hline 4 & Supporting local & $\begin{array}{l}\text { Global trends: buying } \\
\text { local }\end{array}$ & 0.492 & & & & \\
\hline 20 & $\begin{array}{l}\text { Availability of } \\
\text { franchises }\end{array}$ & $\begin{array}{l}\text { Global trends: rejection } \\
\text { of low-cost mass } \\
\text { production food }\end{array}$ & 0.320 & & & & \\
\hline 12 & Vegan & Culture and religion & & -0.827 & & & \\
\hline 11 & Vegetarian & Culture and religion & & -0.795 & & & \\
\hline 10 & Halal & Culture and religion & & -0.751 & & & \\
\hline 9 & Kosher & Culture and religion & & -0.729 & & & \\
\hline 13 & Organic & $\begin{array}{l}\text { Global trends: functional, } \\
\text { organic and animal } \\
\text { welfare-oriented } \\
\text { products }\end{array}$ & & -0.663 & & & \\
\hline 25 & Wine routes & $\begin{array}{l}\text { Availability, quality and } \\
\text { variety }\end{array}$ & & & -0.893 & & \\
\hline 22 & Craft beer & Global trends: craft beer & & & -0.872 & & \\
\hline 23 & Garage wines & $\begin{array}{l}\text { Global trends: garage } \\
\text { wine }\end{array}$ & & & -0.858 & & \\
\hline 24 & Food routes & $\begin{array}{l}\text { Availability, quality and } \\
\text { variety }\end{array}$ & & & -0.763 & & \\
\hline 26 & Culinary events & $\begin{array}{l}\text { Social influences and } \\
\text { self-development }\end{array}$ & & & -0.731 & & \\
\hline
\end{tabular}


The importance of different culinary aspects when travelling - the case of international tourists to South Africa.

\begin{tabular}{|c|c|c|c|c|c|c|c|}
\hline 27 & $\begin{array}{l}\text { Enhance my } \\
\text { knowledge }\end{array}$ & Self-development & & & -0.685 & & \\
\hline 21 & Gourmet cuisine & Global trends: trading up & & & -0.599 & & \\
\hline 31 & $\begin{array}{l}\text { Traditional } \\
\text { cuisine }\end{array}$ & $\begin{array}{l}\text { Desire for authentic food } \\
\text { experience }\end{array}$ & & & & -0.827 & \\
\hline 32 & $\begin{array}{l}\text { Experience a new } \\
\text { culture }\end{array}$ & $\begin{array}{l}\text { Desire for authentic food } \\
\text { experience }\end{array}$ & & & & -0.777 & \\
\hline 29 & $\begin{array}{l}\text { Close to } \\
\text { attractions }\end{array}$ & Dining establishments & & & & -0.775 & \\
\hline 30 & $\begin{array}{l}\text { Esteemed } \\
\text { restaurants }\end{array}$ & $\begin{array}{l}\text { Social influences and } \\
\text { global trends: celebrity } \\
\text { chefs }\end{array}$ & & & & -0.694 & \\
\hline 28 & Child-friendly & Dining establishments & & & & -0.644 & \\
\hline 17 & $\begin{array}{l}\text { Sustainable } \\
\text { seafood }\end{array}$ & $\begin{array}{l}\text { Global trends: } \\
\text { environmental } \\
\text { sustainability }\end{array}$ & & & & & 0.735 \\
\hline 16 & $\begin{array}{l}\text { Sustainable } \\
\text { methods }\end{array}$ & $\begin{array}{l}\text { Global trends: } \\
\text { environmental } \\
\text { sustainability }\end{array}$ & & & & & 0.734 \\
\hline 15 & $100 \%$ natural & $\begin{array}{l}\text { Global trends: clean } \\
\text { eating and whole food }\end{array}$ & & & & & 0.696 \\
\hline 18 & $\begin{array}{l}\text { Reasonably } \\
\text { priced }\end{array}$ & Affordability & & & & & 0.657 \\
\hline 14 & Animal welfare & $\begin{array}{l}\text { Global trends: functional, } \\
\text { organic and animal } \\
\text { welfare-oriented products }\end{array}$ & & & & & 0.619 \\
\hline 19 & Variety of cuisine & $\begin{array}{l}\text { Availability, quality and } \\
\text { variety }\end{array}$ & & & & & 0.516 \\
\hline & \multirow{2}{*}{\multicolumn{2}{|c|}{$\begin{array}{l}\text { Cronbach } \alpha \text { reliability coefficient } \\
\text { Inter-item correlations }\end{array}$}} & 0.824 & 0.898 & 0.919 & 0.842 & 0.834 \\
\hline & & & 0.351 & 0.638 & 0.616 & 0.525 & 0.453 \\
\hline & \multicolumn{2}{|c|}{ Mean value (standard deviation) } & $\begin{array}{l}3.281 \\
(0.677)\end{array}$ & $\begin{array}{l}2.290 \\
(1.112)\end{array}$ & $\begin{array}{l}2.631 \\
(0.988)\end{array}$ & $\begin{array}{l}3.022 \\
(0.916)\end{array}$ & $\begin{array}{l}3.205 \\
(0.829)\end{array}$ \\
\hline
\end{tabular}

culinary experience" and "Environmental sensitivity". For the rest of the study, the factors are highlighted in bold text and the variables in italics.

T-tests were conducted to compare the culinary preference factors with socio-demographic and behavioural questions which only offered two answer categories. The questions analysed with this test were "gender" and "are you currently following any religious, health- or weight-related diet". There was no significant difference between gender and any of the factors. A statistical and practical significant difference between being on a diet or not (which relates to culture and religion, intolerances and allergies and lifestyle) and culture and religion $(\mathrm{p}=0.001 ; d=0.43$; small effect) did, however, exist. The statistically significant differences $(p<0.05)$ between have been marked in grey in Table 5.
Respondents who at the time of data collection were following a religious, health- or weightrelated diet regarded the factor culture and religion to be a more important $($ mean $=2.684$ ) influence on their culinary preferences than those not following a diet $($ mean $=2.212)$.

Spearman rank correlations were conducted in order to assess the direction and strength of the linear relationship between the ranked socio-demographic and behavioural variables and culinary preference factors. The ranked questions were "in what year were you born", "what is your highest educational qualification", "I consider myself to be..." (level of adventurousness when dining), "how many times have you travelled internationally in the last 5 years, including this trip", "how many times (including this trip) have you visited South Africa", "how often do you normally dine out", "during this trip, how many nights did you 
Table 5. Significant t-test results

\begin{tabular}{|c|c|c|c|c|c|c|}
\hline \multirow{2}{*}{ Factors } & & \multicolumn{5}{|c|}{ Currently following any diet } \\
\hline & & Yes / No & Mean & $\begin{array}{l}\text { Std. } \\
\text { Deviation }\end{array}$ & P-value & $\begin{array}{l}\text { Effect } \\
\text { size }\end{array}$ \\
\hline \multirow{10}{*}{ 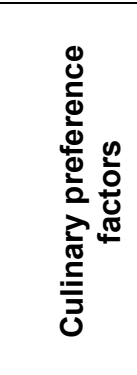 } & \multirow{2}{*}{ Social influences } & Yes & 3.287 & 0.682 & 0.878 & 0.02 \\
\hline & & No & 3.274 & 0.672 & & \\
\hline & \multirow{2}{*}{ Culture and religion } & Yes & 2.684 & 1.088 & 0.001 & 0.43 \\
\hline & & No & 2.212 & 1.096 & & \\
\hline & \multirow{2}{*}{ Exploration } & Yes & 2.491 & 1.054 & 0.247 & 0.14 \\
\hline & & No & 2.641 & 0.959 & & \\
\hline & \multirow{2}{*}{ The culinary experience } & Yes & 3.134 & 1.011 & 0.285 & 0.13 \\
\hline & & No & 3.002 & 0.898 & & \\
\hline & \multirow{2}{*}{ Environmental sensitivity } & Yes & 3.286 & 0.857 & 0.384 & 0.11 \\
\hline & & No & 3.193 & 0.824 & & \\
\hline
\end{tabular}

Table 6. Significant Spearman correlation results

Socio-demographic, travel-profile and behavioural variables

\begin{tabular}{|c|c|c|c|c|c|}
\hline & & Adventurous & $\begin{array}{l}\text { Visits to South } \\
\text { Africa }\end{array}$ & $\begin{array}{l}\text { Frequency of } \\
\text { dining out }\end{array}$ & $\begin{array}{l}\text { Total } \\
\text { spending }\end{array}$ \\
\hline \multirow[t]{2}{*}{ Social influence } & rho & $0.100^{*}$ & $0.109^{*}$ & 0.083 & 0.005 \\
\hline & Sig. (2-tailed) & 0.025 & 0.013 & 0.068 & 0.911 \\
\hline \multirow{4}{*}{$\begin{array}{l}\text { Culture and } \\
\text { religion } \\
\text { Exploration }\end{array}$} & rho & $0.133^{* *}$ & 0.036 & $0.126^{\star *}$ & -0.056 \\
\hline & Sig. (2-tailed) & 0.003 & 0.41 & 0.005 & 0.240 \\
\hline & rho & 0.036 & 0.081 & 0.022 & $0.164^{* *}$ \\
\hline & Sig. (2-tailed) & 0.42 & 0.065 & 0.636 & 0.001 \\
\hline \multirow{4}{*}{$\begin{array}{l}\text { The culinary } \\
\text { experience } \\
\text { Environmental } \\
\text { sensitivity }\end{array}$} & rho & -0.008 &, $090^{\star}$ & -0.023 & $0.095^{*}$ \\
\hline & Sig. (2-tailed) & 0.853 & 0.039 & 0.611 & 0.047 \\
\hline & rho & 0.047 & 0.051 & 0.062 & -0.007 \\
\hline & Sig. (2-tailed) & 0.292 & 0.247 & 0.170 & 0.882 \\
\hline
\end{tabular}

stay in South Africa" and "approximately how much did you spend on this trip in South African Rand (ZAR)". There were no significant correlations between age, education, length of stay or number of international trips (which relates to travel experience and frequency) and any of the culinary preference factors. Significant correlations $(p<0.05)$ between the sociodemographic and travel profile variables and the factors have been highlighted in Table 6 .

The less adventurous respondents considered themselves (which relates to personality) the more important they regarded social influence (rho $=.100$; small correlation) and culture and religion ( $r$ o $=0.133$; small correlation). It seems logical that people restricted by dietary customs and laws in religion would be less adventurous eaters. Likewise, it is no surprise that less adventurous tourists would attach great value to social influence. It indicates that these tourists rely on the recommendations of others in order to make 'safe' and 'informed' culinary decisions.

Respondents who had visited South Africa a number of times (which relates to travel experience and frequency) also regarded social influence to be important to their culinary preferences (rho $=.109$; small correlation). It is possible that tourists who have visited South Africa a number of times either have friends or family in the country or have built relationships with South African colleagues. Either way, they likely value the recommendations of local South Africans when making culinary decisions.

As can be seen in Table 6, the less often respondents dined out the more important they regarded culture and religion (rho $=0.126$; small correlation) to be. This finding alludes to 
the fact that respondents who have dietary requirements due to their cultural and religious affiliations may find it easier to cook for themselves than find restaurants that cater to their needs, causing them to dine out infrequently. Total spending had a positive correlation (rho $=0.164$; small correlation) with the importance of exploration as a culinarypreference factor. It seems that tourists who valued exploring spent more than tourists who valued the other culinary preference factors.

ANOVA was used to draw the comparison of the remaining socio-demographic and behavioural questions with the culinary preference factors. The questions addressed were "what is your nationality", "what was the main purpose of this trip" and "are you familiar with South African cuisine". There was no significant relationship between familiarity with South African cuisine (which relates to past experience) and any of the culinary preference factors. Results from the ANOVA analyses are depicted in Table 7 and 8 . The tables indicate the mean scores for each group as well as the differences between these means. It also shows which of those differences were statistically significant. Post-hoc Tukey tests

Table 7. ANOVA for comparison of factors by nationality

\begin{tabular}{|c|c|c|c|c|c|c|c|c|c|}
\hline \multirow{2}{*}{ Factors } & \multirow{2}{*}{ Nationality } & \multirow{2}{*}{ Mean } & \multirow{2}{*}{$\begin{array}{l}\text { Std. } \\
\text { Devia- } \\
\text { tion }\end{array}$} & \multirow{2}{*}{$\begin{array}{c}\text { F- } \\
\text { value }\end{array}$} & \multirow{2}{*}{$\begin{array}{c}\mathrm{P} \text { - } \\
\text { value }\end{array}$} & \multicolumn{4}{|c|}{ Effect sizes } \\
\hline & & & & & & Africa & Americas & Australia & Europe \\
\hline \multirow{6}{*}{$\begin{array}{l}\text { Social } \\
\text { influence }\end{array}$} & Africa & 3.371 & 0.709 & 2.48 & 0.043 & & & & \multirow{10}{*}{0.14} \\
\hline & Americas & 3.152 & 0.63 & & & 0.309 & & & \\
\hline & Australia & 3.278 & 0.551 & & & 0.132 & 0.199 & & \\
\hline & Europe & 3.193 & 0.664 & & & 0.251 & 0.061 & 0.128 & \\
\hline & Asia & 3.286 & 0.639 & & & 0.12 & 0.209 & 0.013 & \\
\hline & Total & 3.282 & 0.678 & & & & & & \\
\hline \multirow{6}{*}{$\begin{array}{l}\text { Culture and } \\
\text { religion }\end{array}$} & Africa & 2.415 & 1.045 & 10.46 & $<.001$ & & & & \\
\hline & Americas & 1.822 & 1.085 & & & 0.547 & & & \\
\hline & Australia & 2.4 & 1.15 & & & 0.013 & 0.503 & & \\
\hline & Europe & 2.13 & 1.128 & & & 0.253 & 0.273 & 0.235 & \\
\hline & Asia & 2.843 & 1.107 & & & 0.387 & 0.923 & 0.385 & 0.633 \\
\hline & Total & 2.295 & 1.117 & & & & & & \multirow{11}{*}{0.025} \\
\hline \multirow{6}{*}{ Exploration } & Africa & 2.646 & 0.969 & 0.541 & 0.706 & & & & \\
\hline & Americas & 2.508 & 1.073 & & & 0.128 & & & \\
\hline & Australia & 2.714 & 1.233 & & & 0.055 & 0.167 & & \\
\hline & Europe & 2.69 & 0.961 & & & 0.045 & 0.169 & 0.02 & \\
\hline & Asia & 2.666 & 0.955 & & & 0.021 & 0.147 & 0.039 & \\
\hline & Total & 2.631 & 0.993 & \multirow{7}{*}{2.489} & & & & & \\
\hline \multirow{6}{*}{$\begin{array}{l}\text { The culinary } \\
\text { experience }\end{array}$} & Africa & 3.074 & 0.966 & & 0.042 & \multirow{2}{*}{\multicolumn{2}{|c|}{0.204}} & & \\
\hline & Americas & 2.877 & 0.854 & & & & & & \\
\hline & Australia & 2.557 & 0.757 & & & 0.536 & 0.374 & & \\
\hline & Europe & 3.014 & 0.838 & & & 0.062 & 0.16 & 0.545 & \\
\hline & Asia & 3.216 & 0.936 & & & 0.147 & 0.363 & 0.705 & 0.216 \\
\hline & Total & 3.028 & 0.918 & & & & & & \multirow{7}{*}{0.046} \\
\hline \multirow{6}{*}{$\begin{array}{l}\text { Environment } \\
\text { al sensitivity }\end{array}$} & Africa & 3.245 & 0.816 & \multirow[t]{6}{*}{2.387} & 0.05 & & & & \\
\hline & Americas & 2.994 & 0.854 & & & 0.294 & & & \\
\hline & Australia & 3.452 & 0.916 & & & 0.226 & 0.5 & & \\
\hline & Europe & 3.251 & 0.799 & & & 0.007 & 0.301 & 0.22 & \\
\hline & Asia & 3.291 & 0.861 & & & 0.053 & 0.345 & 0.176 & \\
\hline & Total & 3.208 & 0.833 & & & & & & \\
\hline
\end{tabular}


were conducted but will not be reported on as effect sizes "replaces" the test and indicates the practical effect in industry. The statistically significant differences $(p<0.05)$ have been highlighted in grey in the tables. Noteworthy effect sizes have also been highlighted. Small effects $(d=0.2-0.5)$ have been highlighted in light grey, medium effects $(d=0.5-0.8)$ in dark grey and strong effects $(d>0.8)$ in black.

Significant differences $(p<0.05)$ were found between social influence, culture and religion, the culinary experience, environmental sensitivity and nationalities (see Table 7). Table 8 depicts that respondents who visited South Africa for leisure purposes (which relates to the type of tourist) on average rated exploration as the most important (mean $=2.757$ ). They likely allocate the most time to participate in activities such as wine and food routes, culinary events or other culinary activities which could enhance their knowledge. The other respondents have to dedicate the majority of their time to their primary reason for being in the country, such as business or visiting friends or family. Respondents who visited South Africa for reasons other than leisure, business or visiting friends or family on average rated exploration as the least important (mean $=2.346$ ), with a small practical difference of $d=0.401$ from leisure tourists.

Table 8. ANOVA for purpose of trip

\begin{tabular}{|c|c|c|c|c|c|c|c|c|}
\hline \multirow{2}{*}{ Factors } & \multirow{2}{*}{$\begin{array}{l}\text { Accommo- } \\
\text { dation }\end{array}$} & \multirow{2}{*}{ Mean } & \multirow{2}{*}{$\begin{array}{l}\text { Std. } \\
\text { Deviation }\end{array}$} & \multirow{2}{*}{$\begin{array}{c}\text { F- } \\
\text { value }\end{array}$} & \multirow{2}{*}{$\begin{array}{c}\mathrm{P}- \\
\text { value }\end{array}$} & \multicolumn{3}{|c|}{ Effect sizes } \\
\hline & & & & & & Leisure & Business & Friends \\
\hline \multirow{5}{*}{$\begin{array}{l}\text { Social } \\
\text { influence }\end{array}$} & Leisure & 3.195 & 0.618 & 1.926 & 0.124 & & & \\
\hline & Business & 3.347 & 0.67 & & & 0.226 & & \\
\hline & Friends & 3.25 & 0.734 & & & 0.075 & 0.132 & \\
\hline & Other & 3.17 & 0.658 & & & 0.038 & 0.263 & 0.109 \\
\hline & Total & 3.256 & 0.67 & & & & & \\
\hline \multirow{5}{*}{$\begin{array}{l}\text { Culture and } \\
\text { religion }\end{array}$} & Leisure & 2.124 & 1.128 & 1.028 & 0.38 & & & \\
\hline & Business & 2.302 & 1.074 & & & 0.157 & & \\
\hline & Friends & 2.373 & 1.055 & & & 0.221 & 0.066 & \\
\hline & Other & 2.189 & 1.187 & & & 0.055 & 0.095 & 0.155 \\
\hline & Total & 2.25 & 1.109 & & & & & \\
\hline \multirow{5}{*}{ Exploration } & Leisure & 2.757 & 1.022 & 4.294 & 0.005 & & & \\
\hline & Business & 2.71 & 0.905 & & & 0.046 & & \\
\hline & Friends & 2.499 & 0.994 & & & 0.253 & 0.213 & \\
\hline & Other & 2.346 & 1.024 & & & 0.401 & 0.356 & 0.149 \\
\hline & Total & 2.601 & 0.986 & & & & & \\
\hline \multirow{5}{*}{$\begin{array}{l}\text { The } \\
\text { culinary } \\
\text { experience }\end{array}$} & Leisure & 3.017 & 0.912 & 0.062 & 0.98 & & & \\
\hline & Business & 2.993 & 0.908 & & & 0.026 & & \\
\hline & Friends & 2.975 & 0.969 & & & 0.044 & 0.019 & \\
\hline & Other & 3.025 & 0.878 & & & 0.009 & 0.035 & 0.052 \\
\hline & Total & 3.002 & 0.911 & & & & & \\
\hline \multirow{5}{*}{$\begin{array}{l}\text { Environme } \\
\text { ntal } \\
\text { sensitivity }\end{array}$} & Leisure & 3.151 & 0.814 & 0.609 & 0.609 & & & \\
\hline & Business & 3.215 & 0.783 & & & 0.078 & & \\
\hline & Friends & 3.213 & 0.9 & & & 0.069 & 0.002 & \\
\hline & Other & 3.087 & 0.85 & & & 0.075 & 0.15 & 0.14 \\
\hline & Total & 3.172 & 0.826 & & & & & \\
\hline
\end{tabular}


The importance of different culinary aspects when travelling - the case of international tourists to South Africa.

\section{Findings and implications}

The main findings and their implications follow. The first finding relates to the importance of the different determinants of culinary preference. Being able to order from a menu that is easily understandable (communication gap) was the most important to international tourists. This influences the accessibility of food and beverages to tourists. The availability of menus in English was found by $\mathrm{Ab}$ Karim and Chi (2010) in previous research to be an important factor for avid foodies and travellers. These findings confirm that it may be frustrating for tourists to order food and beverages if they cannot understand the language or are not provided with clear pictures of the cuisine on offer at dining establishments (Cincan, 2014). The implication of the above is that pictures on menus could be used, perhaps including pictures of the individual ingredients to assist tourists to identify the dish they would prefer, even if they do not understand the language used on the menu.

The second most important item for respondents in this study was the availability of cuisine that was reasonably priced. Ab Karim and Chi (2010) similarly found a reasonable price (affordability) for dining out to be important to tourists. In Thailand specifically it has been found that when tourists considered different types of dining establishments, they were most likely to select dining from street vendors or locally owned restaurants when only considering the price of these establishments compared to the price of international franchised restaurants and eating establishments at accommodation facilities (Burusnukul et al., 2011).

The third most important item was that the food had to appeal to the respondents' senses. Taste has been found to dominate the dietary domain of tourists (Kittler \& Sucher, 2004; Updhyay \& Sharma, 2014). Taste has also been found to specifically influence the preference for local food among international tourists (Batra, 2008; Abraham \& Kannan, 2015). It has been stated that there is a very real potential for South Africa to influence tourists' tastes and generate permanent export markets (South African Government, 1996). From a practical point of view, servers could be trained to promote local cuisine when serving international customers.

Other practical implications of this finding include that government could increase the availability of information about local cuisine. The Department of Trade and Industry (one of the main drivers of the Proudly South African campaign) could expand to make their logo available for use in menus (Proudly South African, 2015). Policies such as the use of the "Proudly South African" logo to identify local dishes and beverages on menus in restaurants in order to clearly identify and promote local cuisine is thus recommended. South African Tourism (2016) asks tourists to be epicurean adventurers when visiting South Africa, to eat in restaurants showcasing the country's diverse food heritage and support locally made food and beverages in order to promote and sustain the local food culture - this does not help if tourists struggle to identify local cuisine. Fields (2002) states that the lack of pre-consumption knowledge should be addressed in marketing cuisine, which is supported by the current research. If the Proudly South African initiative is not a viable option, printing a small South African flag next to traditional dishes in menus will also assist international tourists to identify local cuisine.

The second finding reveals that all 32 tested culinary preference variables loaded onto the five factors, illustrating that they all play a role in culinary preferences. In addition, the combination of factors has not been found in the literature before and therefore makes an important contribution not only from a culinary point of view but also from a developing country point of view. The five culinary preference factors identified mainly comprised of behavioural and external determinants. The factors were named social influence, culture and religion, exploration, the culinary experience and environmental sensitivity.

Social influence was the most important culinary preference factor $($ mean $=3.281)$. This indicates the importance of influences such as friends' and family's recommendations, good ratings of establishments and effective marketing of local and other cuisine. Overall, these influences were even more important 
than culture and religion (mean $=2.290$; lowest mean of the five factors). This finding supports Triandis' $(1977,1980)$ TIB, who states that social factors influence intentions to perform a behaviour and the finding of Sparks (2007) who found reference groups to be influential. Ryu and Jang (2006) modified the TRA theory and used it to investigate tourists' intentions to consume local food whilst on holiday. The authors recommended that marketers should pay attention to spreading positive word-of-mouth, which is of value in the South African context as well. A South African marketing campaign with a strong culinary focus and a catch phrase may encourage positive word-of-mouth amongst South Africans and international tourists alike. The National Department of Tourism could launch the campaign on multiple platforms, such as television, radio, Twitter, Facebook, brochures etc. An example of what such a campaign might entail is captured in a video entitled 'Food safari Cape Town - where food lovers dreams come true'. This video, made by Swiss tourists, captures the staggering culinary offer (as stated by Stefan - the filmmaker) of the Western Cape. Stefan even goes as far as describing Cape Town as "Essen, Essen, Essen", which means "Eating, Eating, Eating" in German (Lombard, 2015).

The social influence factor further included the availability of pictures outside of businesses, this is an easy addition to culinary outlets to satisfy the needs of international tourists. Complete menus or pictures of popular, signature or local dishes could be considered. Social influence furthermore includes dining at establishments with good ratings, restaurants should thus endeavour to maintain good ratings on travelogues and respond to poor ratings timeously in order to show commitment to customers.

Environmental sensitivity was found to be the second most important culinary preference factor and the culinary experience was the third most important factor. As is evident in global trends, environmental sustainability is becoming all the more important to consumers (Steptoe et al., 1995). Diners are requesting sustainably caught seafood and humanelyraised meat (Stanton, 2015). Food forms a crucial part of the "think globally, act locally" debate. Some tourists prefer supporting local businesses and protecting the environment by avoiding food which had to be transported vast distances (Barcelona Field Studies Centre, 2015). Tourists may even expect menus to indicate exactly where the food originates (Yeoman \& McMahon-Beattie, 2015). Restaurants could give tourists what they want and simultaneously preserve resources in South Africa by opting for sustainable products in their dishes. This important element could be included in the grading and evaluation of restaurants, such as TripAdvisor, the Eat Out restaurant guide and the country's prestigious Eat Out Mercedes-Benz Restaurant Awards (Eat Out 2016; TripAdvisor 2016).

Not only the food itself but also the culinary experience created by restaurants seems to be key in tourists' decisions (Kim et al., 2009). The culinary experience factor included the dining establishment variable. Fields (2002) states that if a dining establishment disappoints in its décor, acoustics or etc., they may spoil the entire experience of dining out. The culinary experience factor also included the desire for an authentic food experience. Tourism developers could thus focus on increasing the availability of traditional cuisine and opportunities to experience a new culture to further enhance tourists' culinary experience. Since tourists who value exploration spent more while in South Africa, the development of more activities for these tourists to explore may be of economic benefit to specific areas.

The third finding of this research is that personality and type of tourist influence culinary preferences. This supports the findings of Cohen and Avieli (2004), Blichfeldt and Halkier (2014) and Mak et al. (2012). These authors mainly found personality and type of tourist to influence the consumption of local foods. The current findings, however, carry new implications. Neophobic tourists valued social influence and culture and religion. Therefore, restauranteurs should offer simple culturally and religiously acceptable meals. Experimentation should rather be aimed at techniques to make a mark on travelogues in order to set these tourists at ease with visiting their establishment. Regarding the type of tourist, establishments who offer activities such 
The importance of different culinary aspects when travelling - the case of international tourists to South Africa.

as craft beer, garage wines, gourmet cuisine, culinary events or other culinary activities which could enhance knowledge could market at tourist attractions and accommodation establishments frequented by leisure tourists.

The fourth finding relates to travel experience and frequency's influence on culinary preferences. It was found that the number of international trips undertaken did not influence culinary preference of international tourists, but the number of times the respondent had visited South Africa did influence their culinary preferences. It has been stated numerous times in the literature that novice travelers tend to avoid local food (Fields, 2002; Ryu \& Jang, 2006; McKercher et al., 2008; D'Antuono \& Bignami, 2012). Since the respondents in the current study who had visited South Africa more than once valued social influence, South Africans should realise their importance in the culinary decision-making of international tourists. Not only professional tourism organisations but also general South Africans have the responsibility to promote local cuisine in order to enhance international tourists' experience in the country as well as increase the economic benefits of cuisine in tourism.

The fifth finding of this research is that the results of this study confirms, but also contradicts previous research regarding sociodemographic determinants of culinary preference. The results contradict the findings of Sloan (2015) that intolerances and allergies influence culinary preference. It also contradicts the findings of Wądołowska et al. (2008) and Ayo et al. (2012) that education plays a role in culinary preferences as well as the findings of (Mak et al., 2012) that gender and age have significant relationships with culinary preference. These contradictions may be due to the unique sample of international tourists to South Africa. This having been stated, the current research does support the findings of (McKercher et al., 2008) who found gender and education not to influence culinary preference during a trip and Devi et al. (2015) who found age to be a slightly insignificant determinant of culinary preferences.

Two of the tested socio-demographic variables were determinants of culinary preferences in the current study. These were nationality and culture and religion, supporting the literature (Steptoe et al., 1995; Cohen \& Avieli, 2004; Chang et al., 2010; Amuquandoh, 2011; Falguera et al., 2012; Horng \& Tsai, 2012; Mak et al., 2012). The practical implications of these findings are that unique marketing strategies aimed at different countries could be developed as different nationalities value different aspects of cuisine. It is also advised that South African culinary establishments offer cuisine to accommodate a variety of religions and cultures.

\section{Conclusions and recommendations}

The aim of this paper was to identify the determinants of culinary preferences of international tourists to South Africa. This study is not only important because tourism is an important sector to the South African economy, but also because food plays such a vital role as a basic necessity and as part of the tourism offering. This study made several contributions. The first contribution made was establishing the determinants of culinary preferences of international tourists as well as the importance of each of these determinants. Five key culinary preference factors based on external and behavioural determinants were determined for the South African context. This is the first of its kind and consequently, makes a literature contribution in the culinary domain of international tourism. Other contributions to academia include that social influence was the most important to international tourists making when making culinary decisions and nationality and culture and religion were the only sociodemographic determinants of culinary preference for international tourists to the country. This research also contributed to a greater understanding of the role of personality and type of tourist on culinary preferences. Another important contribution is the role of frequency of trips and how it influences culinary preferences.

The practical implications of the study include that government should focus on the social influences, environmental sensitivity and the culinary experience offered in South Africa in international tourism marketing campaigns. In essence this research supports the notion that more can be done in the South Africa tourism 
industry to create awareness and promote culinary tourism more effectively. Tourism developers can concentrate on developing attractions to satisfy the needs of international tourists. National and provincial tourism organisations, on the other hand, can run awareness campaigns to make culinary business owners aware of the factors that are the most important to international tourists. The findings could serve as a guideline to tourism and hospitality businesses whose target market include international tourists, who could adjust their food and beverage offerings in order to cater to the needs of international tourists, thereby increasing their sales and profit. Hotels, restaurants and other eateries can develop products and plan menus according to the established preferences of international tourists. Tourism bodies and destination marketers can further use the research findings to market South Africa using the specific culinary items that tourists enjoyed the most, for example chicken and other curries, chicken wings, pap and braai. As South Africa is the least prepared culinary travel destination in the world it is time for some much-needed change (Phillips, 2010).

Additional research into culinary preferences may further increase the impact of the findings and the successful implementation of real change to the benefit of all. Since South Africa is such a diverse country, tourists should be asked which areas they visited if similar studies are conducted in the future. Qualitative research with dining establishment owners, international tourists and policy makers could be considered. Interview questions can be compiled based on the findings which came to light in the present study. Furthermore, research can be conducted into the viability of using the results obtained in the current research as a starting point for developing a rating scale for South African restaurants. Currently, no such rating scale exists. Michelin does not operate in South Africa and the Tourism Grading Council of South Africa (TGCSA) only grades accommodation establishments and meetings, exhibitions and special events venues (Hayler, 2015; Tourism Grading Council of South Africa, 2016).

\section{References}

Ab Karim, S. \& Chi, C.G.-Q. (2010). Culinary tourism as a destination attraction: an empirical examination of destinations' food image. Journal of Hospitality Marketing \& Management. 19(6), 531-555.

Abraham, S. \& Kannan, R.K. (2015). Cluster analysis of young online consumers in Indian context. International Journal of Management. 4(2), 133-148.

Allergy UK. 2015. Why is allergy increasing? [Online], Available: https://www.allergyuk. org/why-is-allergy-increasing/why-isallergy-increasing [2016, April 07].

Amuquandoh, F.E. (2011). International tourists' concerns about traditional foods in Ghana. Journal of Hospitality and Tourism Management, 18(1), 1-9.

Andersen, B.V. \& Hyldig, G. (2015). Consumers' view on determinants to food satisfaction. A qualitative approach. Appetite, 95, 9-16.

Aquilani, B., Laureti, T., Poponi, S. \& Secondi, L. (2015). Beer choice and consumption determinants when craft beers are tasted: an exploratory study of consumer preferences. Food Quality and Preference, 41, 214-224.

Argyle, R. (2016). 7 things to consider when picking a restaurant location. [Online], Available: http://www.foodstart.com/7things-to-consider-when-picking-arestaurant-location [2016, August 17].

Ayo, S., Bonabana-Wabbi, J. \& Sserunkuuma, D. (2012). Determinants of fast food consumption in Kampala, Uganda. African Journal of Food, Agriculture, Nutrition and Development. 12(5), 6567-6581.

Barcelona Field Studies Centre. (2015). Food or gastronomic tourism and rural development. [Online], Available: http://geographyfieldwork.com/FoodTouris m.htm [2016, March 31].

Batra, A. (2008). Foreign tourists' motivation and information source(s) influencing their preference for eating out at ethnic restaurants in Bangkok. International Journal of Hospitality \& Tourism Administration, 9(1), 1-18.

Bigliardi, B. \& Galati, F. (2013). Innovation trends in the food industry: the case of functional foods. Trends in Food Science and Technology, 31(2), 118-129. 
Blichfeldt, B.S. \& Halkier, H. (2014). Mussels, tourism and community development: a case study of place branding through food festivals in rural North Jutland, Denmark. European Planning Studies, 22(8), 15871603.

Burusnukul, P., Binkley, M. \& Sukalakamala, P. (2011). Understanding tourists' patronage of Thailand foodservice establishments: an exploratory decisional attribute approach. British Food Journal, 113(8), 965-981.

Chang, R.C.Y., Kivela, J. \& Mak, A.H.N. (2010). Food preferences of Chinese tourists. Annals of Tourism Research, 37(4), 989-1011.

Chatibura, D. (2015). The development of a strategic framework for the promotion of local cuisine in Botswana. North-West University.

Cincan, A. (2014). 7 good reasons for translating menus in hotel restaurants. [Online], Available: http://inboxtranslation. com/blog/7-good-reasons-translatingmenus-hotel-restaurants/ [2016, October 13].

Cohen, E. \& Avieli, N. (2004). Food in tourism attraction and impediment. Annals of Tourism Research, 31(4), 755-778.

Croce, E. \& Perri, G. (2010). Food and wine tourism. Oxfordshire: CABI.

D'Antuono, L.F. \& Bignami, C. (2012). Perception of typical Ukrainian foods among an Italian population. Food Quality and Preference, 25(1), 1-8.

Daniel, M., Guttmann, Y. \& Raviv, A. (2011). Cooking and Maslow's hierarchy of needs: a qualitative analysis of amateur chefs' perspectives. International Journal of Humanities and Social Science, 1(20), 86-94.

Devi, K.K., Singh, G., Naz, R. \& Fam, K. (2015). Cross-cultural food consumption behavior of consumers in Fiji. International Journal of Business and Economics, 14(1), 105-126.

Eat Out. (2016). Awards. [Online], Available: http://www.eatout.co.za/awards/ [2016, December 09].

Elzinga, K.G., Tremblay, C.H. \& Tremblay, V.J. (2015). Craft beer in the United States: history, numbers, and geography. Journal of Wine Economics, 10(3), 242-274.
Falguera, V., Aliguer, N. \& Falguera, M. (2012). An integrated approach to current trends in food consumption: moving toward functional and organic products? Food Control, 26(2), 274-281.

Field, A. (2013). Discovering statistics using IBM SPSS statistics. 4th ed. London: SAGE Publications Ltd.

Fields, K. (2002). Demand for the gastronomy tourism product: motivational factors. In Tourism and gastronomy. A. Hjalager \& G. Richards, Eds. London: Routledge.36-50.

Figus, C. (2014). 375 million vegetarians worldwide. All the reasons for a green lifestyle. [Online], Available: http://www. expo2015.org/magazine/en/lifestyle/375million-vegetarians-worldwide.html [2016, October 15].

Food and Beverage Magazine. (2014). TV celebrity chef becomes British ambassador for food, drink and tourism. [Online], Available: https://www.fb101. com/2014/05/tv-celebrity-chef-becomesbritish-ambassador-for-food-drink-andtourism [2016, March 31].

Gardner, C. (2014). Transversality, deterritorialization, and the A.O.C.- constructing lines of flight from flights of wine. Contemporary French and Francophone Studies, 18(2), 142-149.

Getz, D., Robinson, R.N.S., Andersson, T. \& Vujicic, S. (2014). Foodies and food tourism. Oxford: Goodfellow Publishers Limited.

Gómez-Corona, C., Lelievre-Desmas, M., Escalona Buendía, H.B., Chollet, S. \& Valentin, D. (2016). Craft beer representation amongst men in two different cultures. Food Quality and Preference, 53, 19-28.

Hair, J.F., Black, W.C., Babin, B.J. \& Anderson, R.E. (2010). Multivariate data analysis: a global perspective. 7th ed. Upper Saddle River: Pearson Education.

Hall, C.M. (2004). Small firms and wine and food tourism in New Zealand: issues of collaboration, clusters and lifestyles. In Small firms in tourism - international perspectives. R. Thomas, Ed. Oxford: Elsevier. 167-181.

Hattingh, Z. (2015). Culture, religion and food rituals. In D. Kokt (Ed.) Hospitality 
management - a practical introduction. Bloemfontein: Sun Press, pp. 127-133.

Hayler, A. (2015). What are some Michelin starred restaurants in South Africa? [Online], Available: https://www.quora.com What-are-some-Michelin-starred-restaurants-in-South-Africa [2016,December 09]. Horng, J.-S. \& Tsai, C.-T. (Simon). (2012). Constructing indicators of culinary tourism strategy: an application of resource-based theory. Journal of Travel \& Tourism Marketing, 29(8), 796-816.

Horng, J.S. \& Tsai, C.T.S. (2010). Government websites for promoting East Asian culinary tourism: a cross-national analysis. Tourism Management, 31(1), 74-85.

Ignatov, E. \& Smith, S. (2006). Segmenting Canadian culinary tourists. Current Issues in Tourism, 9(3), 235-255.

Ivanovic, M. (2008). Cultural tourism. Cape Town: Juta \& Company.

de Jonge, J., van der Lans, I.A. \& van Trijp, H.C.M. (2015). Different shades of grey: compromise products to encourage animal friendly consumption. Food Quality and Preference, 45, 87-99.

Kim, Y.G. \& Eves, A. (2012). Construction and validation of a scale to measure tourist motivation to consume local food. Tourism Management, 33(6), 1458-1467.

Kim, Y.G., Eves, A. \& Scarles, C. (2009). Building a model of local food consumption on trips and holidays: a grounded theory approach. International Journal of Hospitality Management, 28(3), 423-431.

Kittler, P.G. \& Sucher, K.P. (2004). Accent on taste: an applied approach to multicultural competency. Diabetes Spectrum, 17(4), 200-204.

Kline, R.B. (2016). Principles and practice of structural equation modeling. 4th ed. New York: The Guildford Press.

Krejcie, R.V. \& Morgan, D.W. (1970). Determining sample size for research activities. Educational and Psychological Measurement, 30(3), 607-610.

Lagerkvist, C.J., Normann, A. \& Åström, A. (2017). Product satisfaction in food choice is multiple-reference dependent: evidence from an in-store non-hypothetical consumer experiment on bread. Food Quality and Preference, 56(Part A), 8-17.
Leedy, P.D. \& Ormrod, J.E. (2014). Practical research: planning and design. 10th ed. Edinburgh Gate: Pearson Education Limited.

Li, J.T.C. (2014). What's the difference between a food intolerance and food allergy? [Online], Available: http://www. mayoclinic.org/diseases-conditions/foodallergy/expert-answers/food-allergy/faq20058538 [2016, April 07].

Lin, Y.-C., Pearson, T.E. \& Cai, L. a. (2011). Food as a form of destination identity: a tourism destination brand perspective. Tourism and Hospitality Research, 11(1), 30-48.

Lombard, L. (2015). WATCH: Swiss couple document their Cape travels as the ultimate "Food Safari". [Online], Available: http://traveller24.news24.com/MyTravels/ WATCH-Swiss-couple-document-theirCape-travels-as-the-ultimate-Food-Safari20150909 [2016, August 11].

Mak, A.H.N., Lumbers, M., Eves, A. \& Chang, R.C.Y. (2012). Factors influencing tourist food consumption. International Journal of Hospitality Management, 31(3), 928-936.

McDonald, P. (2014). Social, demographics and cultural trends and consumer preferences. In Drivers of change for the Australian labour market to 2030. K. Barnes \& P. Spearritt, Eds. Canberra: The academy of the social sciences in Australia. 35-42.

McKercher, B., Okumus, F. \& Okumus, B. (2008). Food tourism as a viable market segment: it's all how you cook the numbers! Journal of Travel \& Tourism Marketing, 25(2), 137-148.

Merriam-Webster Dictionary. (2015). Whole food. [Online], Available: http://www. merriam-webster.com/dictionary/whole food [2016, April 07].

Moodley, C. (2016). SA must brace for bumper tourism year. [Online], Available: 10 June 2016.

Napolitano, F., Castellini, C., Naspetti, S., Piasentier, E., Girolami, A. \& Braghieri, A. (2013). Consumer preference for chicken breast may be more affected by information on organic production than by product sensory properties. Poultry Science, 92(3), 820-826.

National Department of Tourism. (2011). 
The importance of different culinary aspects when travelling - the case of international tourists to South Africa.

Packaged Facts. (2014). Food formulation trends: ingredients consumers avoid. [Online], Available: http://www.packaged facts.com/Food-Formulation-Trends8024542/ [2016, April 07].

Phillips, J. (2010). Culinary tourism industry report released. [Online], Available: http://www.tourismupdate.co.za/home/det ail ?articleid $=21128 \&$ article $=$ culinarytourism-industry-report-released [2016, January 19].

Proudly South African. (2015). Proudly South African annual report 2014/15. Johannesburg.

Quan, S. \& Wang, N. 2004. Towards a structural model of the tourist experience: An illustration from food experiences in tourism. Tourism Management, 25(3), 297-305.

Du Rand, G.E. \& Heath, E. (2006). Towards a framework for food tourism as an element of destination marketing. Current Issues in Tourism, 9(3), 206-234.

Du Rand, G.E., Heath, E. \& Alberts, N. (2003). The role of local and regional food in destination marketing: a South African Situation Analysis. Journal of Travel \& Tourism Marketing, 14(3-4), 97-112.

Restaurant Engine. (2015). What makes for a great restaurant location? [Online], Available: http://restaurantengine.com/gr eat-restaurant-location/ [2016, August 17].

Robinson, R.N.S. \& Getz, D. (2014). Profiling potential food tourists: an Australian study. British Food Journal, 116(4), 690-706.

Ronco, F. (2015). Garage wines contest. [Online], Available: http://www.terroirvino. it/eng-garage-wines-contest.htm [2016, June 02].

Rozin, P. \& Vollmecke, T.A. (1986). Food likes and dislikes. Annual review of nutrition, 6(1), 433-456.

Ryan, C. (1994). Tourism and leisure - the application of leisure concepts to tourist behaviour - a proposed model. In Tourism: The state of the art. A. Steaton, Ed. London: Cassell. 194-205.

Ryu, K. \& Jang, S. (2006). Intention to experience local cuisine in a travel destination: the modified theory of reasoned action. Journal of Hospitality \& Tourism Research, 30(4), 507-516.
Saayman, M. \& Scholtz, M. (2012). Visitors perceptions of the non-consumptive value of selected species and game-viewing experiences in South African national parks. Potchefstroom: Tourism Research in Economic Environs and Society.

Sánchez-Cañizares, S.M. \& López-Guzmán, T. (2012). Gastronomy as a tourism resource: profile of the culinary tourist. Current Issues in Tourism, 15(3),229-245.

Sloan, A.E. (2015). The top ten food trends. Food Technology, 69(4). [Online], Available: http://www.ift.org/food-technolo gy/past-issues/2015/april/features/the-topten-food-trends.aspx?page=viewall.

Smith, C. (2016). By the numbers: 23 amazing TripAdvisor statistics. [Online], Available: http://expandedramblings.com/index.php/t ripadvisor-statistics/ [2016, August 26].

Smith, M.K. (2009). Issues in cultural tourism studies. 2nd ed. New York: Routledge.

South African Government. (1996). Development and promotion of tourism white paper. [Online], Available: http://www.gov.za/documents/developmen t-and-promotion-tourism-south-africawhite-paper [2016, January 19].

South African Tourism. (2014). 2013 annual tourism performance report. [Online], Available: http://www.southafrica.net/ research/en/landing/research-home [2015, June 10].

South African Tourism. (2016). South African food conservation. [Online], Available: http://www.southafrica.net/za/en/articles/e ntry/article-south-african-foodconservation [2016, January 19].

Sparks, B. (2007). Planning a wine tourism vacation? Factors that help to predict tourist behavioural intentions. Tourism Management, 28(5), 1180-1192.

Stanton, J. (2015). What's new? Mindful dining to influence restaurant trends in 2015. [Online], Available: http://blog.elevate research.com/whats-new-mindful-diningto-influence-restaurant-trends-in-2015 [2016, April 07]

Statistics South Africa. (2016). Tourism, 2015. [Online], Available: http://www.statssa. gov.za/publications/Report-03-5102/Report-03-51-022015.pdf $[2016$ September 04]. 
Steptoe, A., Pollard, T.M. \& Wardle, J. (1995). Development of a measure of the motives underlying the selection of food: the Food Choice Questionnaire. Appetite, 25(3), 267-284.

Steyn, S. (2015). Developing a framework for the optimisation of the image of South Africa as a tourism destination. NorthWest University.

Su, Y. (2015). Reflections on local specialties and gastronomic tourism. Chinese Studies, 4(1), 15-19.

Tikkanen, I. (2007). Maslow's hierarchy and food tourism in Finland: five cases. British Food Journal, 109(9), 721-734.

Torres, R. (2002). Toward a better understanding of tourism and agriculture linkages in the Yucatan: tourist food consumption and preferences. Tourism Geographies: An International Journal of Tourism Space, Place and Environment, 4(3), 282-306.

Tourism Grading Council of South Africa. (2016). Grading criteria. [Online], Available: http://www.tourismgrading.co.za /get-graded/whats-in-it-for-me/gradingcriteria-3/ [2016, December 09].

Triandis, H.C. (1977). Interpersonal behavior. Monterey: Brooks/Cole.

Triandis, H.C. (1980). Values, attitudes, and interpersonal behavior. In Nebraska symposium on motivation 1979. H.E. Howe \& M.M. Page, Eds. Lincoln: University of Nebraska Press. 195-259.

United Nations. (2015). Tourism highlights. [Online], Available: http://www.capetown. travel/uploads/files/UNWTO_Highlights_2 015.pdf [2015, April 15].
Updhyay, Y. \& Sharma, D. (2014). Culinary preferences of foreign tourists in India. Journal of Vacation Marketing. 20(1), 2939.

Wądołowska, L., Babicz-Zielińska, E. \& Czarnocińska, J. (2008). Food choice models and their relation with food preferences and eating frequency in the Polish population: POFPRES study. Food Policy, 33(2), 122-134.

Wahba, P. (2016). Sam's Club bets on fancier food to steal customers from Costco. [Online], Available: http://finance.yahoo. com/news/sam-club-bets-fancier-food173306488.html [2016, February 24].

White Hutchinson. (2007). Kids dining out is not child's play. [Online], Available: https://www.whitehutchinson.com/news/le news/2007_august/article102.shtml [2016, August 17].

Williams, H.A., Williams, R.L. \& Omar, M. (2014). Gastro-tourism as destination branding in emerging markets markets. International Journal of Leisure and Tourism Marketing, 4(1), 1-18.

Wongprawmas, R. \& Canavari, M. (2015). Heterogeneity in consumer preferences for food safety label in Thailand. [Online], Available:

http://ageconsearch.umn.edu/bitstream/20 2744/2/236.pdf [2015, July 22].

Yeoman, I. \& McMahon-Beattie, U. (2015). The future of food tourism: the Star Trek replicator and exclusivity. In I. Yeoman, U. McMahon-Beattie, K. Fields, J.N. Albrecht, \& K. Meethan (Eds.) The future of food tourism. Bristol: Channel View Publications, pp. 23-48. 